\title{
Effect of Prophylactic Ligation of the Thoracic Duct on Long-Term Survival in Patients Undergoing Esophagectomy: A Meta-Analysis
}

\section{Mei kun}

Third Affiliated Hospital of Soochow University: Changzhou First People's Hospital

\section{Ce Chao}

Third Affiliated Hospital of Soochow University: Changzhou First People's Hospital

\section{Long Xuanren}

Third Affiliated Hospital of Soochow University: Changzhou First People's Hospital

\section{Ma Chao}

Third Affiliated Hospital of Soochow University: Changzhou First People's Hospital

\section{Zhou Rui}

Third Affiliated Hospital of Soochow University: Changzhou First People's Hospital

\section{Wang Bin ( $\nabla$ colin_iverson@163.com )}

Third Affiliated Hospital of Soochow University: Changzhou First People's Hospital

\section{Dongmei}

Third Affiliated Hospital of Soochow University: Changzhou First People's Hospital

\section{Research}

Keywords: esophagectomy, esophageal cancer, thoracic duct, long-term survival『overall survival

Posted Date: March 15th, 2021

DOl: https://doi.org/10.21203/rs.3.rs-298896/v1

License: (c) (i) This work is licensed under a Creative Commons Attribution 4.0 International License. Read Full License 


\section{Abstract}

Objective: To evaluate the existing literature by comparing long-term survival between patients who underwent prophylactic thoracic duct ligation (PLG) and non-prophylactic thoracic duct ligation (NPLG) during esophagectomy for esophageal cancer, a meta-analysis of relevant studies was conducted.

Background: The effect of PLG and NPLG on the long-term survival in patients undergoing esophagectomy for treatment of esophageal cancer has not been established.

Methods: All articles searches were performed in PubMed, Cochrane, Embase, and Web of Science, and the deadline is August 31, 2020. The search terms included esophagectomy AND thoracic duct. The selected articles compared the long-term survival of patients undergoing esophagectomy to treat esophageal cancer with prophylactic thoracic duct ligation (PLG) and non-prophylactic thoracic duct ligation (NPLG). The $P^{2}$ test and $X^{2}$ test were used to determine statistical heterogeneity. Publication bias was assessed using the Egger test. The results are presented as hazard ratios (HRs) with $95 \%$ confidence intervals (Cls). All data analysis was performed using Stata12.0 software.

Result: A total of 4418 patients from eight studies were included in this meta-analysis. Pooled analysis revealed that a high overall survival (OS) was significantly associated with NPLG (HR=0.81, 95\% Cl: 0.74$0.88, P<.001$ ), while the recurrence- free survival (RFS) and disease-free survival (DFS) were not significantly different $(\mathrm{HR}=1.02,95 \% \mathrm{Cl}: 0.71-1.45, \mathrm{P}<.001)$. There was no statistical difference in longterm survival among patients with different stages of esophageal cancer, while patients who underwent esophagectomy after 2019 had a better long-term prognosis (HR=0.57, 95\% Cl: 0.57-0.79). In addition, there was no significant difference in prognosis and survival between patients in Japan and China based on regional analysis.

Conclusions: Our meta-analysis showed that NPLG was associated with better long-term survival. Thus, we should preserve the thoracic duct during esophageal cancer surgery.

\section{Introduction}

Esophageal cancer is the seventh leading cause of cancer deaths worldwide (1). At present, esophagectomy is the most effective method to treat localized esophageal cancer (2-7). Prophylactic ligation of the thoracic duct (PLG) during esophageal cancer surgery is controversial. To reduce the morbidity associated with chylothorax, ligation of the thoracic duct should be performed prophylactically independent of intra-operative injury to the thoracic duct; however, PLG may result in post-operative intravenous volume loss, hemodynamic instability, and a delay in initiating enteral feeding $(8,9)$. Indeed, the effect of PLG on long-term survival in patients undergoing esophagectomy for esophageal cancer has not been established (9-13). Therefore, the purpose of our meta-analysis was to evaluate the long-term survival of PLG during esophagectomy for esophageal cancer.

\section{Materials And Methods}




\subsection{Search strategy}

PubMed, Cochrane, Embase, and Web of Science were searched for relevant studies that evaluated the long-term survival in esophageal cancer patients post-esophagectomy. The search terms included esophagectomy AND thoracic duct. In addition, references in the retrieved literature were manually reviewed. This study was a meta-analysis, so ethical approval was not required.

\subsection{Inclusion and exclusion criteria}

Inclusion criteria and methods of the analysis have been pre-defined and documented.

Studies were independently screened by two authors (Mei and Chao) according to the title, abstract, and type of article. The literature search had no language restrictions. The retrieved articles were included in the meta-analysis if all of the following criteria were met:

1. the article contained non-prophylactic thoracic duct ligation (NPLG) and PLG groups;

2. the article provided original data and sufficient information to estimate the hazard ratio (HR) for thoracic duct ligation;

3. Non-prophylactic thoracic duct ligation (NPLG) and PLG and prognosis of cancer patients were described. HR and $95 \% \mathrm{Cl}$ are reported, or can be obtained indirectly through survival curve.

The exclusion criteria:

1. Without sufficient data;

2. Case reports, reviews, summaries of meetings or discussions.

\subsection{Quality assessment}

Two investigators (Mei and Chao) independently assessed the eligible studies in accordance with the Newcastle-Ottawa Quality Assessment Scale (NOS) (14). NOS scores of at least six were considered highquality literature. Higher NOS scores showed higher literature quality.

\subsection{Data extraction}

One researcher extracted the data from the selected articles and the other researcher checked the extracted data. The following data were extracted:

1. first author, publication year, sample size, methods, duration of follow-up, and other relevant data; and 
2. the overall survival rate (OS) and $95 \%$ confidence interval (Cls) were extracted if the data were clearly provided in the published study results; if survival data were not provided, survival data were extracted from the Kaplan-Meier curve for further processing (15).

Disagreements between reviewers were resolved by consensus.

\subsection{Statistical analysis}

The HR and $95 \% \mathrm{Cl}$ were used to assess the long-term effects of thoracic duct ligation and a test for heterogeneity was also performed using $R^{2}$ tests (16). If a $X^{2}$ test had a $\mathrm{P} \otimes 0.05$ or $2 \nabla 50 \%$, we considered the heterogeneity to be significant, and a random-effect model was adopted; otherwise, a fixed-effects model was adopted. A Begg funnel plot was used to detect publication bias. Data management and analysis were performed with STATA 12.0 software (Stata Corporation, College Station, TX, USA).

\section{Results}

\subsection{Search results}

As shown in the following flow chart, a total of 1292 studies were retrieved from PubMed, Cochrane, Embase, and Web of Science according to the search strategy. Of the 1292 studies, 615 were duplicates and deleted. A total of 643 studies were excluded based on abstract screening, including 568 unrelated studies, 60 cases, 12 reviews, and two letters. After reading through the entire study, 26 studies lacking data were excluded. Finally, eight studies were analyzed囚FIG. $1 \otimes(10,17-23)$.

\subsection{Study characteristics}

Detailed information about the eight studies is available in Table 1. The eight studies were published between 2006 and 2020, including four each conducted in Japan and China. A total of 4418 patients (2128 and 2290 underwent NPLG and PLG, respectively) were included. Kaplan-Meier curves were provided in all studies. The $\mathrm{HR}$ and $95 \% \mathrm{Cl}$ were provided in the Chen study (18), and the corresponding $\mathrm{HR}$ and $95 \% \mathrm{Cl}$ were extracted by Kaplan-Meier curve for the other studies that did not provide direct data. The NOS scores ranged from 7-8.

\subsection{Correlation between NPLG and HR of cancer patients}

Due to the low heterogeneity of the study, the fixed-effect model was used $\left(I^{2}=14.5 \%, p=0.306\right)$. The following forest map (Fig. 2) shows the correlation between NPLG and long-term patient survival $\triangle H R=0.81,95 \% \mathrm{Cl}: 0.74-0.88, \mathrm{P} \otimes 0.001)$. In addition, the RFS was not statistically significant $\triangle \mathrm{HR}=1.02$, $95 \% \mathrm{Cl}: 0.71-1.45, \mathrm{p}=0.293 \rrbracket$ 
The OS for different esophageal cancer stages were not statistically significant (Figs. 3 ).

Compared with patients undergoing esophagectomy before and after 2019, Patients who underwent esophagectomy after 2019 had a better prognosis ( $\mathrm{HR}=0.67,95 \% \mathrm{Cl}: 0.57-0.79, \mathrm{p}=0.689)$ than patients who underwent esophagectomy before 2019 , which may have reflected the improvement in surgical techniques (Figs. 4).

A comparison of esophageal cancer patients in different geographic regions revealed statistical significance in both groups, but there was no significant difference (Figs. 5).

\subsection{Publication bias}

The Begg funnel plot showed similar symmetry, suggesting no publication bias (Begg test: $P=0.815$ and Egger test: $P=0.705 ;$ Fig. $6 \otimes$ Moreover, the Egger test was performed to assess the publication bias of the included studies $(10,17-23)$.

\section{Discussion}

The thoracic duct, the largest lymphatic vessel in the body, originates from hemangioblastic stem cells and generally develops at the end of the $6^{\text {th }}$ week of gestation. In an adult, the thoracic duct is located at T12 - L2 to the right of the midline. The thoracic duct courses cranially to enter the thorax through the aortic hiatus. The posterior thoracic duct is often damaged during esophagectomy because of adhesions of the esophagus to adjacent soft tissues. In addition, this finding may be due to variations in the thoracic duct due to embryonic developmental deviations, which can occur in any part of the duct circuit. So, there are a number of studies involving routine ligation of the thoracic duct (24-29).

In the past decade, the majority of studies have focused on PLG for reducing the incidence of postoperative chylothorax, but few studies have addressed long-term survival. Tao (23) reported that PLG is a safe and effective method to reduce post-operative chylothorax. Both Satoru (22) and Matsuda (17) concluded that ligation has a superior effect on long-term prognosis.

A number of studies, however, have shown that PLG may have adverse outcomes. For example, PLG has been shown to increase the incidence of post-operative chylothorax and left recurrent laryngeal nerve (RLN) palsy (21). In addition, it has also been clarified that routine PLG is not necessary $(19,20)$. Furthermore, Hou (10) and Chen (18) investigated the effect of PLG on long-term survival, and reported that the PLG group had a lower 5-year survival rate than the NPLG group $(48.2 \%$ vs. $61.6 \%, P<0.001)$.

Therefore, we performed this meta-analysis to obtain more definitive conclusions on the effects of NPLG and PLG on long-term survival in patients undergoing esophagectomy for esophageal cancer. In fact, more and more researchers have shown that NPLG has a better prognosis. This is the first meta-analysis to determine the effect of PLG and NPLG on long-term survival of esophageal cancer patients. 
Specifically, our findings suggested that NPLG has a higher long-term survival rate in patients with esophageal cancer. Eight studies and 4418 patients were included, indicating good reliability of the results. The pooled HR value was 0.81 (95\% Cl: 0.74-0.88, $\mathrm{P}<0.001)$.

Furthermore, because the thoracic duct has immune and nutrition functions, injury to the thoracic duct leads to chylothorax, which in turn leads to weakened immune function, malnutrition, impaired respiratory function, and decreased plasma proteins, fat-soluble vitamins, triglycerides, lymphocytes, electrolytes, and endovascular volume. Therefore, the difference in RFS between the PLG and NPLG groups in this study was not significant, while the OS was statistically significant $(24-27,29)$.

In addition, some limitations to this study should be discussed and studied. The results of this metaanalysis showed some heterogeneity $\left(I^{2}=14.5 \%\right)$. The lack of standardized ligation techniques may be one reason for the heterogeneity. For example, Chen (18) performed PLG by ligation of lymphoid adipose tissue between the aorta and the singular artery, whereas Hou (10) performed direct ligation near the diaphragmatic hiatus. The HR was obtained using Engauge Digitizer 10.0 software from the KaplanMeier curve, which may have been a source of error. In addition, the articles collected in this study only included studies conducted in China and Japan, which may be representative of Asia, thus additional data should be collected, especially for patient groups in Europe and the United States. The selected articles in this study were all retrospective studies, with no prospective studies. Therefore, a large prospective study should be conducted to verify our results.

Drinking milk before surgery can help with thoracic duct imaging and reduce intra-operative injury. In addition, contrast-enhanced multi-row computed tomography with axial and coronal multi-plane reconstruction may also be used to display the thoracic duct.

\section{Conclusion}

This meta-analysis showed that NPLG has a better long-term survival rate for patients with esophageal cancer. Therefore, PLG should be avoided during esophagectomy

\section{Abbreviations}

PLG prophylactic thoracic duct ligation

NPLG non-prophylactic thoracic duct ligation

HRs hazard ratios

Cls confidence intervals

OS overall survival

RFS recurrence- free survival 
DFS disease-free survival

NOS Newcastle-Ottawa Quality Assessment Scale

RLN recurrent laryngeal nerve

SE standard error

CSS cause-specific survival

\section{Declarations}

\section{Conflict of Interest}

The authors declare that the research was conducted in the absence of any commercial or financial relationships that could be construed as a potential conflict of interest.

\section{Author Contributions}

MK, CC, and BW conceived and designed the study. MK drafted the original paper. MK, CC, and XRL extracted all data and performed the analyses. CM, RZ, and DMD supervised the project and provided direction and guidance throughout the preparation of this manuscript. BW revised the final manuscript. All authors contributed to the article and approved the submitted version.

\section{Funding}

This work was supported by The National Natural Science Fund (81701584ه冈Funding from Young Talent Development Plan of Changzhou Health Commission(CZQM2020004), Basic Research Project of Changzhou science and Technology Bureau (CJ20200104) and Social Development Projects of Changzhou science and Technology Bureau (CE20205039).

\section{Availability of date and materials}

All the date analyzed in this study are obtained from the original articles.

\section{Ethics approval and consent to participate}

This study was a meta-analysis, so ethical approval was not required.

\section{Consent for publication}

Not applicable.

\section{References}


1. Fitzmaurice C, Akinyemiju TF, Al Lami FH, Alam T, Alizadeh-Navaei R, Allen C, et al. Global, Regional, and National Cancer Incidence, Mortality, Years of Life Lost, Years Lived With Disability, and Disability-Adjusted Life-Years for 29 Cancer Groups, 1990 to 2016: A Systematic Analysis for the Global Burden of Disease Study. JAMA oncology. 2018;4(11):1553-68.

2. Hofstetter W, Swisher SG, Correa AM, Hess K, Putnam JB Jr, Ajani JA, et al. Treatment outcomes of resected esophageal cancer. Annals of surgery. 2002;236(3):376-84. discussion 84 - 5.

3. Hölscher AH. [About the commentary reference from Baumhoer D, Ramadori D. Contemporary therapy of esophageal carcinoma. Z. Gastroenterol 2004; 42: 171-174. About the article from Hulscher et al. Extended transthoracic resection compared with limited transhiatal resection for adenocarcinoma of the esophagus, N Engl.J Med 2002; 347: 1662-1669]. Zeitschrift fur Gastroenterologie. 2004;42(4):344.

4. Hulscher JB, Tijssen JG, Obertop H, van Lanschot JJ. Transthoracic versus transhiatal resection for carcinoma of the esophagus: a meta-analysis. Ann Thorac Surg. 2001;72(1):306-13.

5. Omloo JM, Lagarde SM, Hulscher JB, Reitsma JB, Fockens P, van Dekken H, et al. Extended transthoracic resection compared with limited transhiatal resection for adenocarcinoma of the mid/distal esophagus: five-year survival of a randomized clinical trial. Annals of surgery. 2007;246(6):992-1000. discussion - 1.

6. Rice TW, Rusch VW, Apperson-Hansen C, Allen MS, Chen LQ, Hunter JG, et al. Worldwide esophageal cancer collaboration. Diseases of the esophagus: official journal of the International Society for Diseases of the Esophagus. 2009;22(1):1-8.

7. Wijnhoven BP, Tran KT, Esterman A, Watson DI, Tilanus HW. An evaluation of prognostic factors and tumor staging of resected carcinoma of the esophagus. Annals of surgery. 2007;245(5):717-25.

8. Gottlieb-Vedi E, Kauppila JH, Malietzis G, Nilsson M, Markar SR, Lagergren J. Long-term Survival in Esophageal Cancer After Minimally Invasive Compared to Open Esophagectomy: A Systematic Review and Meta-analysis. Annals of surgery. 2019;270(6):1005-17.

9. Crucitti P, Mangiameli G, Petitti T, Condoluci A, Rocco R, Gallo IF, et al. Does prophylactic ligation of the thoracic duct reduce chylothorax rates in patients undergoing oesophagectomy? A systematic review and meta-analysis. European journal of cardio-thoracic surgery: official journal of the European Association for Cardio-thoracic Surgery. 2016;50(6):1019-24.

10. Hou X, Fu JH, Wang X, Zhang LJ, Liu QW, Luo KJ, et al. Prophylactic thoracic duct ligation has unfavorable impact on overall survival in patients with resectable oesophageal cancer. European journal of surgical oncology: the journal of the European Society of Surgical Oncology the British Association of Surgical Oncology. 2014;40(12):1756-62.

11. Cagol M, Ruol A, Castoro C, Alfieri R, Michieletto S, Ancona E. Prophylactic thoracic duct mass ligation prevents chylothorax after transthoracic esophagectomy for cancer. World journal of surgery. 2009;33(8):1684-6.

12. Lai FC, Chen L, Tu YR, Lin M, Li X. Prevention of chylothorax complicating extensive esophageal resection by mass ligation of thoracic duct: a random control study. Ann Thorac Surg. 
2011;91(6):1770-4.

13. Guo W, Zhao YP, Jiang YG, Niu HJ, Liu XH, Ma Z, et al. Prevention of postoperative chylothorax with thoracic duct ligation during video-assisted thoracoscopic esophagectomy for cancer. Surgical endoscopy. 2012;26(5):1332-6.

14. Stang A. Critical evaluation of the Newcastle-Ottawa scale for the assessment of the quality of nonrandomized studies in meta-analyses. Eur J Epidemiol. 2010;25(9):603-5.

15. Wang M, Chao C, Luo G, Wang B, Zhan X, Di D, et al. Prognostic significance of TRIM59 for cancer patient survival: A systematic review and meta-analysis. Medicine. 2019;98(48):e18024.

16. Zintzaras E, loannidis JP. HEGESMA: genome search meta-analysis and heterogeneity testing. Bioinformatics. 2005;21(18):3672-3.

17. Matsuda S, Kawakubo H, Takeuchi H, Hayashi M, Mayanagi S, Takemura R, et al. Minimally invasive oesophagectomy with extended lymph node dissection and thoracic duct resection for early-stage oesophageal squamous cell carcinoma. Br J Surg. 2020;107(6):705-11.

18. Chen JY, Liu QW, Zhang SS, Li JB, Yang H, Wen J, et al. Prophylactic thoracic duct ligation is associated with poor prognosis and regional lymph node relapse in esophageal squamous cell carcinoma. Journal of surgical oncology. 2020;122(2):336-43.

19. Yoshida N, Nagai Y, Baba Y, Miyamoto Y, Iwagami S, Iwatsuki M, et al. Effect of Resection of the Thoracic Duct and Surrounding Lymph Nodes on Short- and Long-Term and Nutritional Outcomes After Esophagectomy for Esophageal Cancer. Ann Surg Oncol. 2019;26(6):1893-900.

20. Fu JH, Hu Y, Huang WZ, Yang H, Zhu ZH, Zheng B. [Evaluating prophylactic ligation of thoracic duct during radical resection of esophageal carcinoma]. Ai zheng $=$ Aizheng $=$ Chinese journal of cancer. 2006;25(6):728-30.

21. Oshikiri T, Takiguchi G, Miura S, Goto H, Otsubo D, Hasegawa $H$, et al. Thoracic Duct Resection During Esophagectomy Does Not Contribute to Improved Prognosis in Esophageal Squamous Cell Carcinoma: A Propensity Score Matched-Cohort Study. Ann Surg Oncol. 2019;26(12):4053-61.

22. Matsuda S, Takeuchi H, Kawakubo H, Shimada A, Fukuda K, Nakamura R, et al. Clinical outcome of transthoracic esophagectomy with thoracic duct resection: Number of dissected lymph node and distribution of lymph node metastasis around the thoracic duct. Medicine. 2016;95(24):e3839.

23. Bao T, Wang YJ, Li KK, Liu XH, Guo W. Short- and long-term outcomes of prophylactic thoracic duct ligation during thoracoscopic-laparoscopic McKeown esophagectomy for cancer: a propensity score matching analysis. Surgical endoscopy. 2020;34(11):5023-9.

24. Defize IL, Schurink B, Weijs TJ, Roeling TAP, Ruurda JP, van Hillegersberg R, et al. The anatomy of the thoracic duct at the level of the diaphragm: A cadaver study. Annals of anatomy = Anatomischer Anzeiger: official organ of the Anatomische Gesellschaft. 2018;217:47-53.

25. Ilahi M, St Lucia K, Ilahi TB. Anatomy. Thorax, Thoracic Duct. StatPearls. Treasure Island (FL): StatPearls Publishing. Copyright @ 2020, StatPearls Publishing LLC.; 2020.

26. Johnson OW, Chick JF, Chauhan NR, Fairchild AH, Fan CM, Stecker MS, et al. The thoracic duct: clinical importance, anatomic variation, imaging, and embolization. European radiology. 
2016;26(8):2482-93.

27. Novelli PM, Chan EG, Frazier AA, Villa Sanchez M. Interventional Therapies for Thoracic Duct Injury and Intractable Chylothorax. J Thorac Imaging. 2019;34(4):258-65.

28. Rao DV, Chava SP, Sahni P, Chattopadhyay TK. Thoracic duct injury during esophagectomy: 20 years experience at a tertiary care center in a developing country. Diseases of the esophagus: official journal of the International Society for Diseases of the Esophagus. 2004;17(2):141-5.

29. Schurink B, Defize IL, Mazza E, Ruurda JP, Brosens LAA, Roeling TAP, et al. Two-Field Lymphadenectomy During Esophagectomy: The Presence of Thoracic Duct Lymph Nodes. Ann Thorac Surg. 2018;106(2):435-9.

\section{Tables}

\section{Table 1. Basic characteristics of the included studies}

OS=overall survival, DFS=disease-free survival, CSS=cause-specific survival, RFS=recurrence-free survival, $\mathrm{HR}=$ hazard ratio, $\mathrm{Cl}=$ confidence interval

\begin{tabular}{|c|c|c|c|c|c|c|c|c|c|}
\hline duther & Year & TDP & TDS & Study type & $\begin{array}{l}\text { OS/CSS/ } \\
\text { DPS/ARS }\end{array}$ & Nos & $\begin{array}{l}\text { Pollow-up } \\
\text { Time }\end{array}$ & HiR & $954 C 1$ \\
\hline $\begin{array}{l}\text { T. Ozbiki } \\
\text { ri. }\end{array}$ & 2019 & 122 & 122 & $\begin{array}{l}\text { retrospecti } \\
\text { ve cohort } \\
\text { etruds }\end{array}$ & $\begin{array}{l}\text { A OS. DPS } \\
\text {. CSS }\end{array}$ & 7 & $\begin{array}{l}\text { aedian } \\
\text { follow-up } \\
\text { 4 } 5 \text { rame }\end{array}$ & 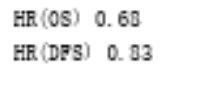 & $\begin{array}{l}\mathrm{CI}(\mathrm{OS}): 0.45-1.03 \\
\mathrm{CI}(\mathrm{DFS}): 0.55-1.24\end{array}$ \\
\hline Tao Bao & 2019 & 40 & 133 & $\begin{array}{l}\text { retrospecti } \\
\text { ve cohort }\end{array}$ & & 7 & - & 1.07 & $0.58-1.97$ \\
\hline $\begin{array}{l}\text { Satoru } \\
\text { Matzuda. }\end{array}$ & 2010 & $\begin{array}{l}\text { oStage I-36 } \\
\text { oStage II- } \\
\text { TV-45 }\end{array}$ & $\begin{array}{l}\text { oStage I-34 } \\
\text { oStage II- } \\
\text { TV-36 }\end{array}$ & $\begin{array}{l}\text { retrospecti } \\
\text { ve cohort } \\
\text { study }\end{array}$ & i os & 7 & - & $\begin{array}{l}\text { HR (cStage I) } 0.8 \\
\text { HR (cStage II- } \\
\text { IV) } 0.85\end{array}$ & $\begin{array}{l}\text { CI (cStage I } \\
) ; 0.06-9.89 \\
\text { CI (cStage II- }\end{array}$ \\
\hline Pu & 2000 & 218 & 171 & $\begin{array}{l}\text { retrospecti } \\
\text { ve cohort }\end{array}$ & & $a$ & $3-156$ wonth & 0.94 & $0.76-1.15$ \\
\hline $\begin{array}{l}\text { S. Matzud } \\
\text { a }\end{array}$ & 2020 & $\begin{array}{l}\text { CTIXo-14 } \\
\text { CTIXI-6 } \\
\text { Stage II-14 } \\
\text { Stage III } \\
\text { or IV-6 }\end{array}$ & $\begin{array}{l}\text { CTINo- } 79 \\
\text { CTIN1 }-15 \\
\text { Stage II }-42 \\
\text { Stage III or } \\
\text { TV-55 }\end{array}$ & $\begin{array}{l}\text { retrospecti } \\
\text { ve cohort } \\
\text { study }\end{array}$ & i RPS & 7 & 6-60anth & $\begin{array}{l}\text { HR (Cr1No) 6. } 16 \\
\text { HR (CrIN1) 1. } 86 \\
\text { HR (Stage II) 1. } 78 \\
\text { ER (Stage III or } \\
\text { IV) } 1.66\end{array}$ & $\begin{array}{l}C I(C r 1 N 0)=0.80- \\
43.11 \\
C I(C r 1 N 1)=0.11- \\
32.57 \\
C I(\text { Stage II }): 0.63-\end{array}$ \\
\hline I. Bou & 2014 & 815 & 989 & $\begin{array}{l}\text { retrospecti } \\
\text { ve cohort }\end{array}$ & & 7 & 3-120month & 0.85 & $0.75-0.96$ \\
\hline $\begin{array}{l}\text { Naoya } \\
\text { Yochida. }\end{array}$ & 2019 & $\begin{array}{l}\text { ostage } \\
\text { I-190 }\end{array}$ & $\begin{array}{l}\text { oStage I-25 } \\
\text { oStage II }-24\end{array}$ & $\begin{array}{l}\text { retrozpecti } \\
\text { ve cohort }\end{array}$ & i os & 7 & 3-60anth & $\begin{array}{l}\text { HR (cStage I) } 0.38 \\
\text { HR (cStage II) } 0.53\end{array}$ & $\begin{array}{l}\text { CI (cStage I):0.03- } \\
4.97\end{array}$ \\
\hline & & $\begin{array}{l}\text { oStage } \\
\text { II-62 } \\
\text { oStage }\end{array}$ & $\begin{array}{l}\text { oStage III-79 } \\
\text { oStage IV-13 }\end{array}$ & study & & & & $\begin{array}{l}\text { HiR (cStage } \\
\text { III) } 0.74 \\
\text { HRR (cStage IV) } 1.73\end{array}$ & $\begin{array}{l}\mathrm{CI} \text { (cStage } \\
\text { II) :0.21-1. } 33 \\
\mathrm{CI} \text { (cStage }\end{array}$ \\
\hline $\begin{array}{l}\text { Jun-Ying } \\
\text { Chen } \\
\text { ND, } \mathrm{PhD}\end{array}$ & 2020 & 402 & 473 & $\begin{array}{l}\text { retrospecti } \\
\text { ve cohort } \\
\text { study }\end{array}$ & i 08 & 7 & 3-60month & 0.63 & $0.52-0.63$ \\
\hline
\end{tabular}

\section{Figures}




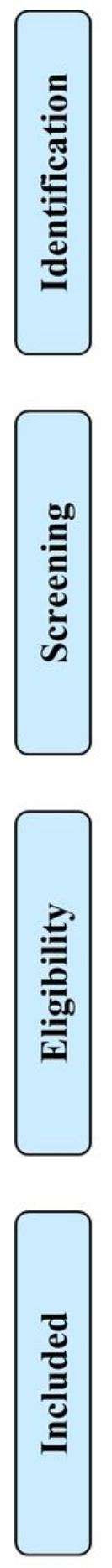

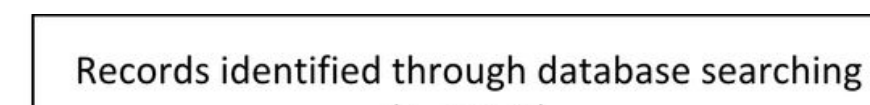

$$
\text { ( } n=1292 \text { ) }
$$

Additional records identified through other sources

$(n=0)$
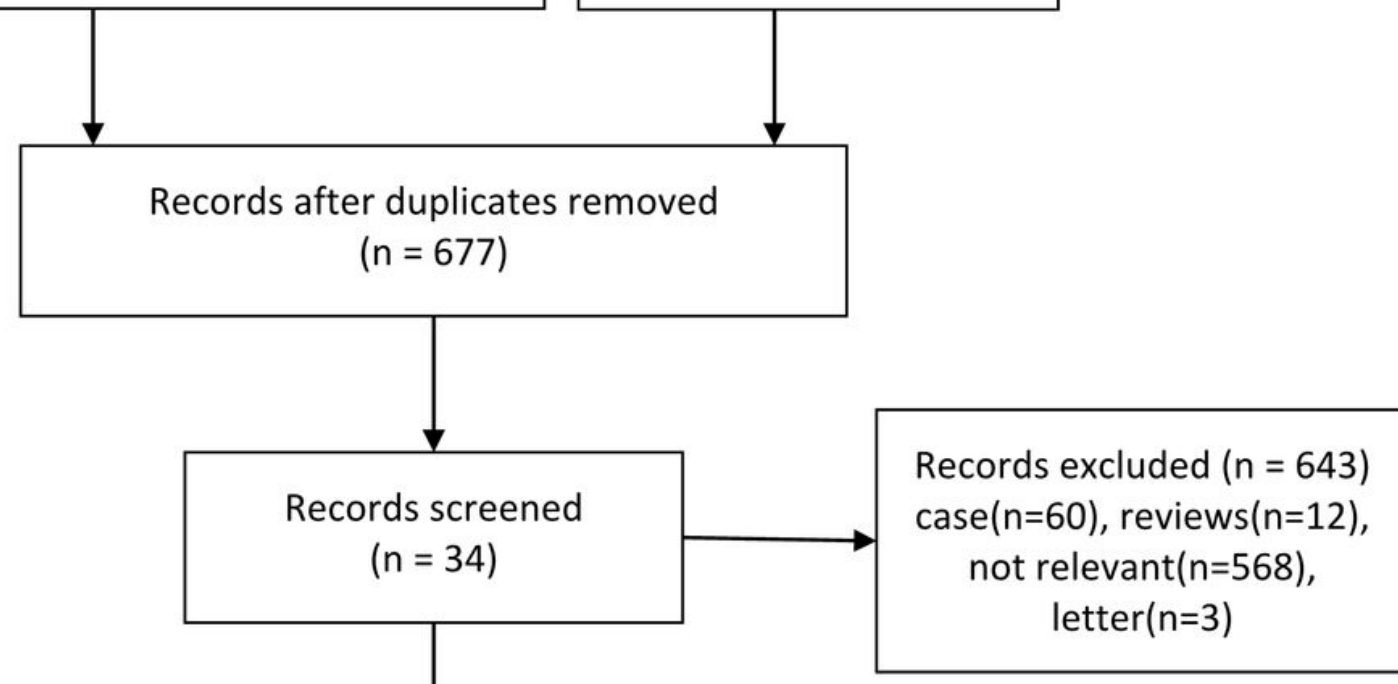

\begin{tabular}{|c|c|}
\hline $\begin{array}{c}\text { Full-text articles assessed } \\
\text { for eligibility } \\
(\mathrm{n}=8)\end{array}$ & $\begin{array}{c}\text { Full-text articles excluded, } \\
\text { with reasons }(\mathrm{n}=26) \\
\text { Without sufficient data }\end{array}$ \\
\cline { 3 - 3 }
\end{tabular}

Studies included in qualitative synthesis

$$
(n=8)
$$

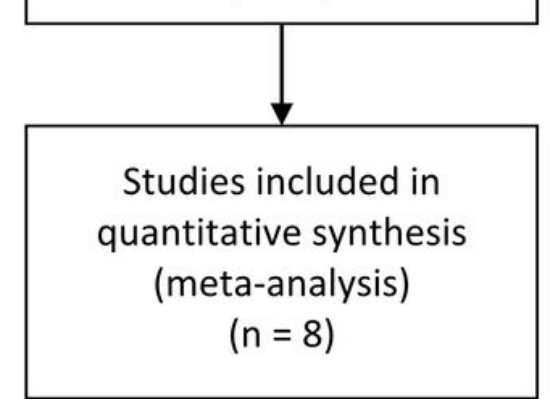

Figure 1

Flowchart of meta-analysis. 


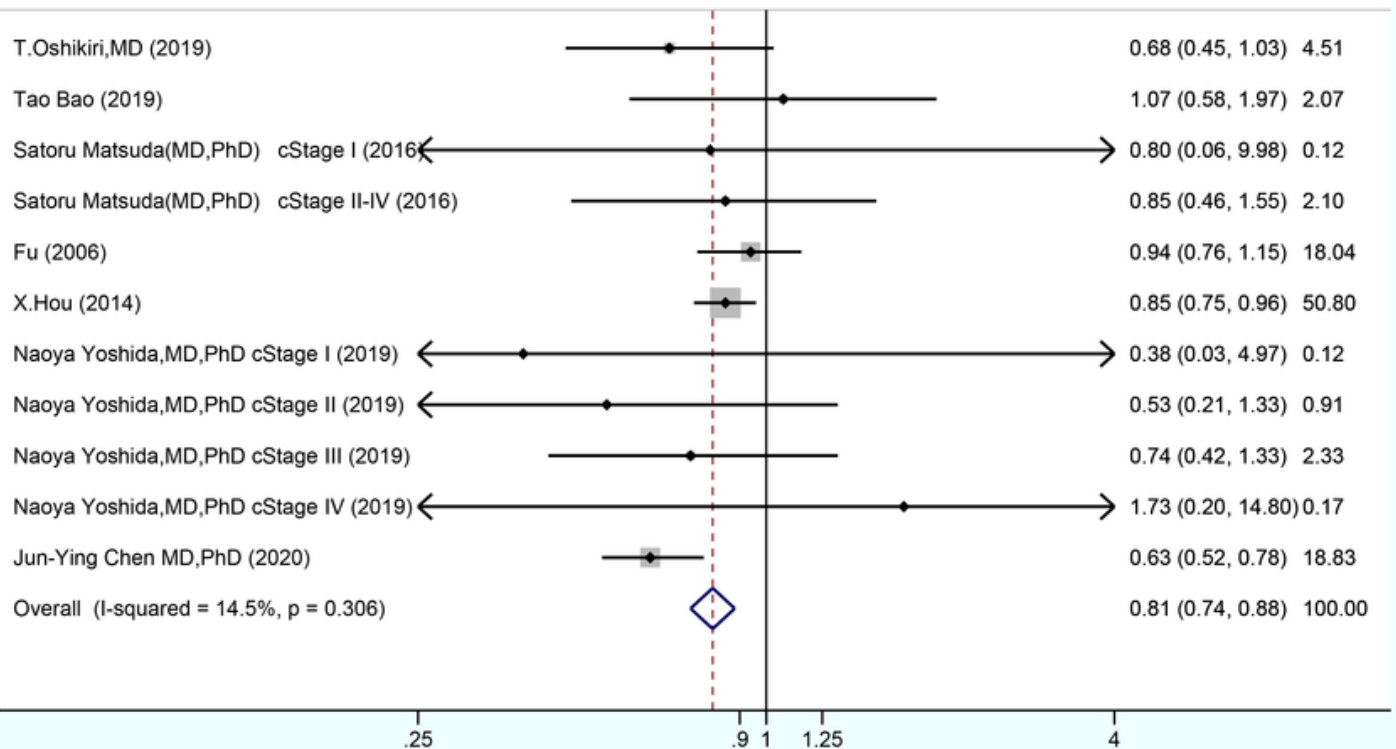

B

Study

ID $\operatorname{hr}(95 \% \mathrm{Cl}) \quad$ Weight

\begin{tabular}{|c|c|c|}
\hline S.Matsuda & CT1NO(stage I) (2020) & \\
\hline S.Matsuda & CT1N1(stage I) (2020) & $\leftarrow$ \\
\hline S.Matsuda & Stage II (2020) & \\
\hline S.Matsuda & Stage III or IV (2020) & \\
\hline \multicolumn{2}{|c|}{ T.Oshikiri,MD (2019) } & \\
\hline \multicolumn{2}{|c|}{ Overall (I-squared $=19.2 \%, p=0.293$ ) } & \\
\hline
\end{tabular}

\section{Figure 2}

Forest plot of the association between NPLG and overall survival in esophageal cancer. HR=hazard ratio, $\mathrm{Cl}=$ confidence interval 
A

Study

hr $(95 \% \mathrm{Cl}) \quad$ Weight

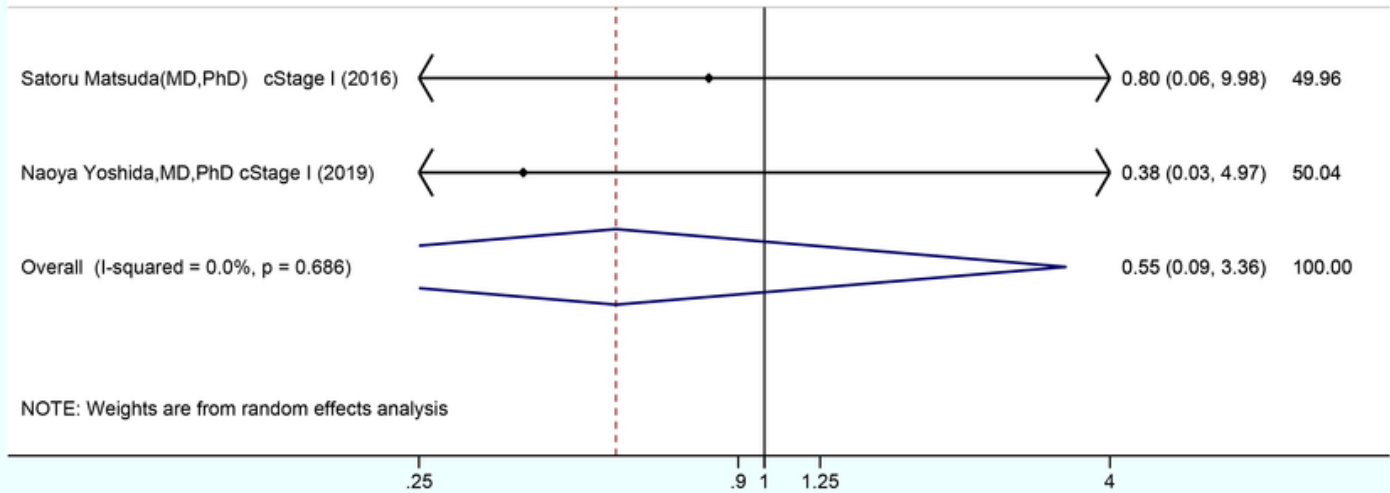

B

Study

$\operatorname{hr}(95 \% \mathrm{Cl}) \quad$ Weight

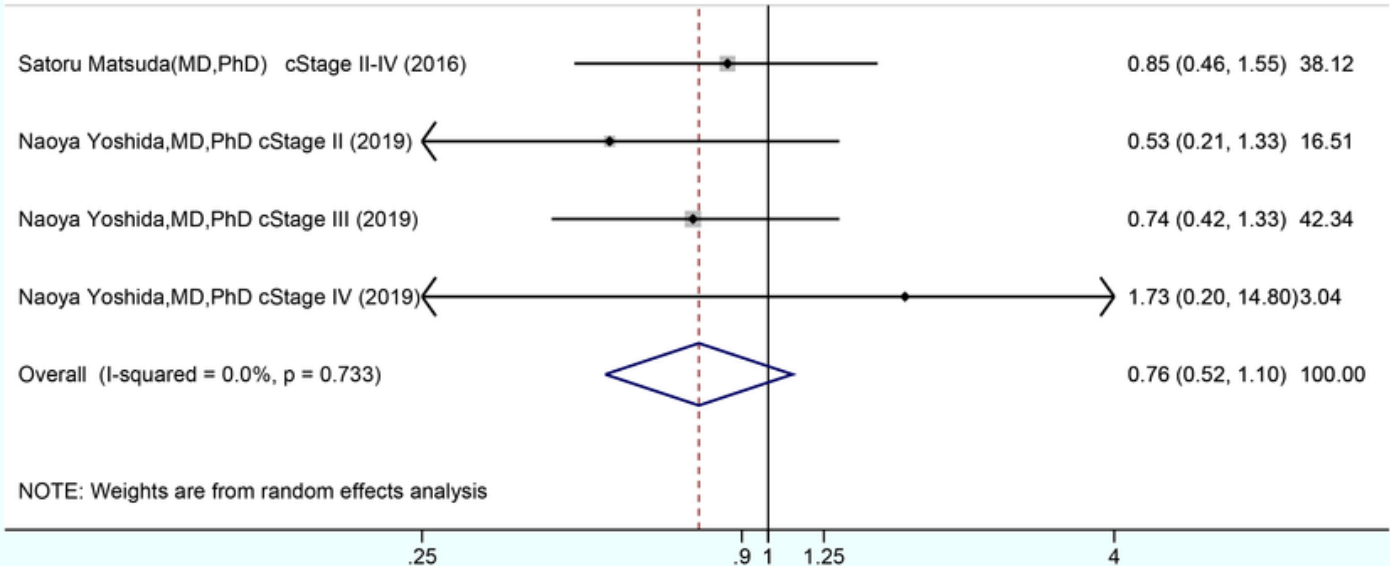

\section{Figure 3}

A: Forest plot of stage I esophageal cancer. B: Forest plot of stage II-IV esophageal cancer. HR=hazard ratio, $\mathrm{Cl}=$ confidence interval 


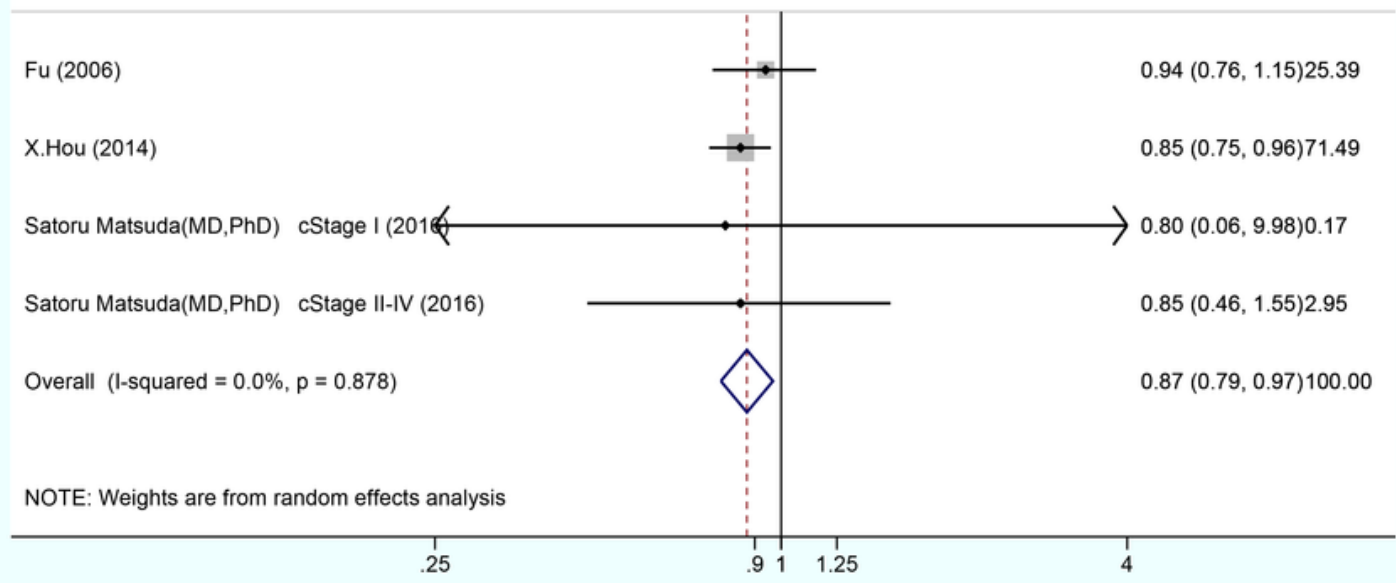

B

Study

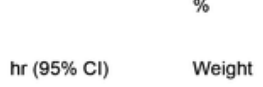

T.Oshikiri,MD (2019)

Tao Bao (2019)

Naoya Yoshida,MD,PhD cStage I (2019)

Naoya Yoshida,MD,PhD cStage II (2019)

Naoya Yoshida,MD,PhD cStage III (2019)

Naoya Yoshida,MD,PhD cStage IV (2019)

Jun-Ying Chen MD,PhD (2020)

Overall (1-squared $=0.0 \%, p=0.689)$

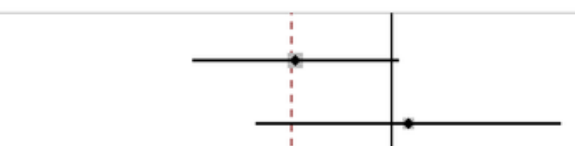

$0.68(0.45,1.03)$

$1.07(0.58,1.97)$

7.15

$0.38(0.03,4.97) \quad 0.41$

$0.53(0.21,1.33) \quad 3.14$

$0.74(0.42,1.33) \quad 8.05$

\section{9)}

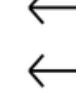

NOTE: Weights are from random effects analysis

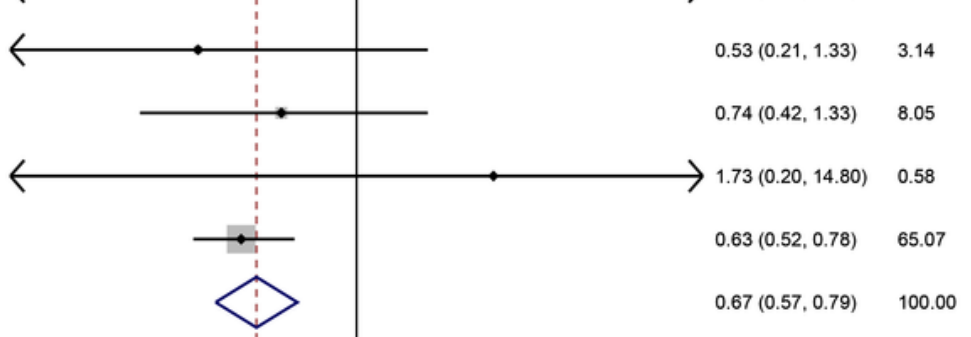

\section{Figure 4}

A: Forest plot of esophagectomy for esophageal cancer before 2019. B: Forest plot of esophageal cancer surgery after 2019. HR=hazard ratio, $\mathrm{Cl}=$ confidence interval 
A

Study

hr $(95 \% \mathrm{Cl}) \quad$ Weight

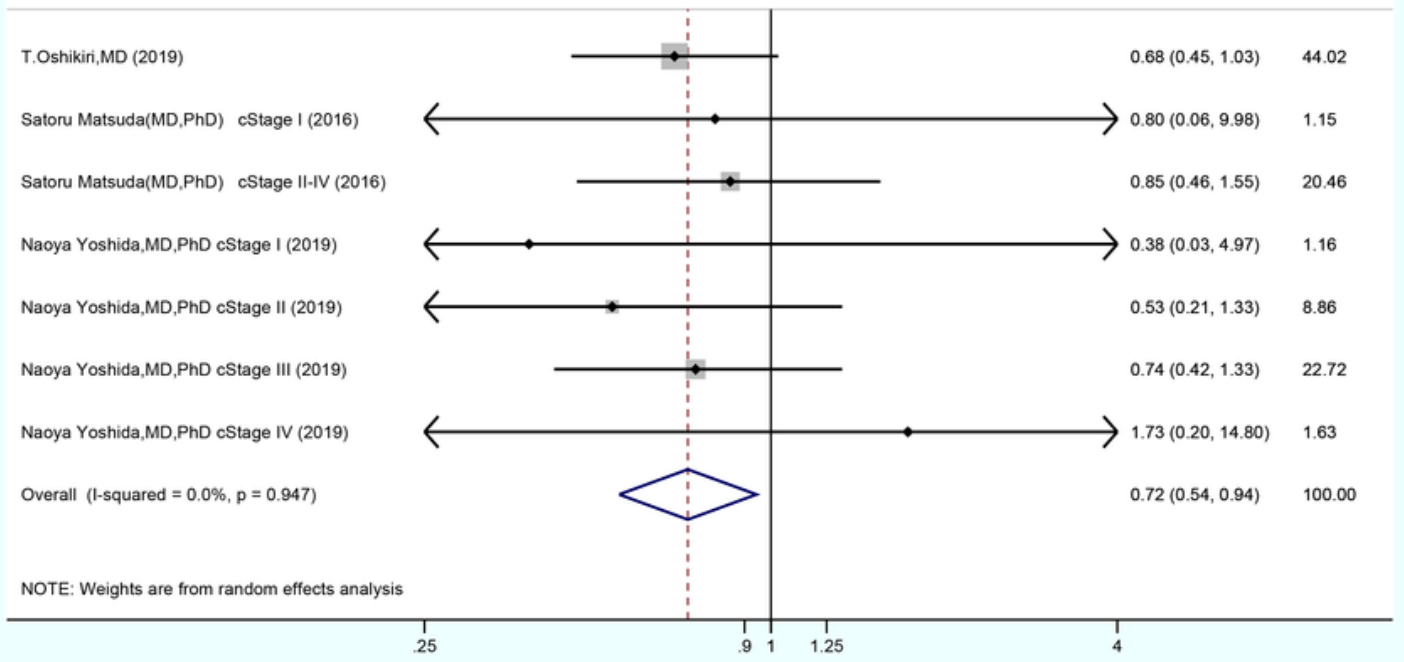

B

Study

$\%$

ID

hr $(95 \% \mathrm{Cl}) \quad$ Weight

Jun-Ying Chen MD,PhD (2020)

$\mathrm{Fu}(2006)$

Tao Bao (2019)

X.Hou (2014)

Overall (I-squared $=67.5 \%, p=0.027$ )

NOTE: Weights are from random effects analysis

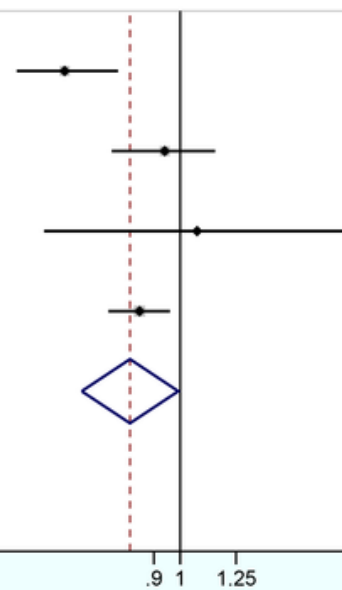

$0.63(0.52,0.78)$

28.45

$0.94(0.76,1.15) \quad 28.07$

$1.07(0.58,1.97) \quad 8.05$

$0.85(0.75,0.96) \quad 35.43$

$0.82(0.67,0.99) \quad 100.00$

\section{Figure 5}

A: Forest plot of esophageal cancer surgery in Japan. B: Forest plot of esophageal cancer surgery in China. $\mathrm{HR}=$ hazard ratio, $\mathrm{Cl}=$ confidence interval 
Begg's funnel plot with pseudo $95 \%$ confidence limits

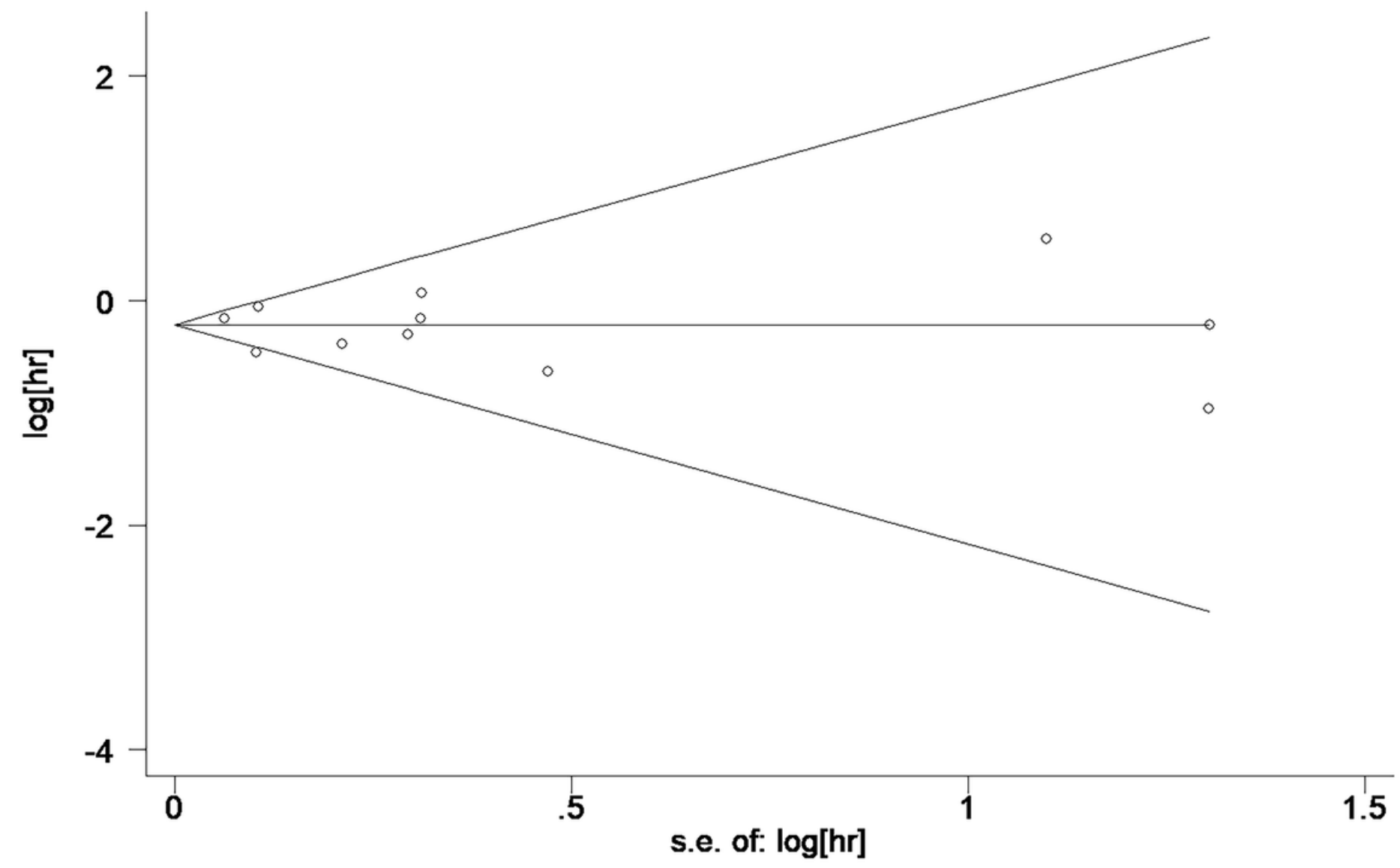

Figure 6

Begg funnel plot indicator test for publication bias of NPLG and overall survival. HR=hazard ratio, $\mathrm{SE}=$ standard error 